\title{
Peningkatan Kemampuan Penalaran Matematis Siswa SMA Melalui Problem Based Learning
}

\author{
Kartika Apriani ${ }^{1}$, Iik Nurhikmayati ${ }^{2}$, M. Gilar Jatisunda ${ }^{3}$ \\ Pendidikan Matematika (FKIP, Universitas Majalengka) \\ email: kartikaapriani04@gmail.com
}

\begin{abstract}
Abstrak-Siswa masih sebagian besar mengalami kesulitan dalam memecahkan masalah matematika. Tujuan penelitian ini adalah untuk mendeskripsikan perbedaan kemampuan penalaran matematis siswa sebelum dan sesudah pembelajaran dengan menggunakan Problem Based Leaarning dan mendeskripsikan perbedaan peningkatan kemampuan penalaran matematis siswa yang menggunakan Problem Based Learning ditinjau dari kemampuan awal matematis (tinggi, sedang, dan rendah). Metode penelitian ini adalah pre-eksperimental. Teknik pengambilan sampel purposive sampling dimana sampel yang diambil adalah kelas XI MIPA 3 dengan jumlah siswa 32 orang yang terdiri dari 4 orang siswa dan 28 orang siswi. Teknik analisis dalam penelitian ini yaitu analisis data kuantitatif diperoleh dari hasil pretest dan posttest dengan uji t (Paired Sample T-Test) dan uji One-Way ANOVA. Hasil penelitian menunjukkan bahwa (1) Perbedaan kemampuan penalaran matematis siswa sesudah pembelajaran lebih baik daripada sebelum pembelajaran dengan menggunakan Problem Based Learning; (2) Terdapat perbedaan peningkatan kemampuan penalaran matematis siswa dengan menggunakan Problem Based Learning ditinjau dari kemampuan awal matematis (tinggi, sedang, dan rendah); (3) Hasil analisis angket respon siswa juga menunjukkan bahwa sebagian besar siswa memiliki respon positif terhadap penggunaan Problem Based Learning dengan nilai rata-rata keseluruhan sebesar $51,63 \%$.
\end{abstract}

Kata kunci: Kemampuan Penalaran Matematis, Problem Based Learning 


\section{PENDAHULUAN}

Matematika merupakan salah satu ilmu yang dapat dimanfaatkan dalam kehidupan nyata. Salah satu manfaat dari matematika yaitu dapat memecahkan permasalahan, baik dalam soal matematika atau permasalahan lainnya yang berkaitan dengan kehidupan nyata dengan daya nalar yang baik. Menurut Sumartini (2015: 1) pendidikan matematika di sekolah ditujukan agar siswa memiliki daya nalar yang baik terutama ketika menyelesaikan masalah dalam mata pelajaran matematika.

Belajar matematika di sekolah diharapkan siswa tidak hanya memiliki kemampuan berhitung saja, tetapi kemampuan daya nalar yang logis, sistematis, analitis, dan kreatif dalam memecahkan masalah harus dimiliki oleh siswa agar tujuan pembelajaran matematika dapat tercapai. Tujuan pembelajaran matematika yang dirumuskan oleh National Council of Teacher of Mathematics (2000: 4) yaitu: (1) Problem solving, (2) Reasoning and Proof, (3) Communication, (4) Connections, (5) Representations. Salah satu dari tujuan pembelajaran matematika yaitu reasoning, artinya siswa diharapkan untuk mampu mengembangkan kemampuan penalarannya sehingga siswa mampu mendalami ide-ide dan proses mengkonstruksi pengetahuannya dalam bidang matematika baik itu memecahkan masalah, menyusun bukti dan menarik kesimpulan. Hal ini menunjukkan bahwa kemampuan penalaran matematis sangat penting.

Mengingat pentingnya kemampuan penalaran matematis harus dimiliki siswa, Nuridawani dkk (2015: 60) menyatakan bahwa kemampuan penalaran matematis merupakan salah satu bagian yang utama yang hendak dicapai dalam tujuan pembelajaran matematika. Hal tersebut diperjelas oleh Sumartini (2015: 4) bahwa kemampuan penalaran matematis membantu siswa dalam menyimpulkan dan membuktikan suatu pernyataan, membangun gagasan baru, sampai pada menyelesaikan masalah-masalah dalam matematika. Oleh karena itu, kemampuan penalaran matematis harus selalu dibiasakan dan dikembangkan dalam setiap pembelajaran matematika.

Jika kemampuan penalaran matematis dibiasakan dan dikembangkan dalam pembelajaran yang melibatkan siswa untuk berpikir logis dan kritis, menyelesaikan masalah, menyusun bukti, menarik kesimpulan dan menjelaskan gagasan matematika maka siswa tersebut dapat dikatakan telah memiliki keterampilan penalaran yang baik.

Namun berdasarkan berbagai penelitian, kemampuan penalaran siswa masih rendah, dilihat jawaban siswa pada soal ulangan yang berbentuk essay menunjukkan bahwa siswa umumnya kurang mampu memberikan penjelasan dengan menggunakan gambar dan kurang mampu memberikan argumenargumen logis dalam menyelesaikan soal-soal matematika, lemah dalam melakukan analisis suatu masalah dan dalam menarik kesimpulan, apalagi ketika melakukan pembuktian suatu teorema.

Mengingat rendahnya kemampuan penalaran matematis dan kompetensi yang harus dimiliki siswa, maka pembelajaran yang dilakukan harus berpusat pada siswa (student center) dengan menggunakan model pembelajaran yang tepat. Model pembelajaran yang digunakan sangat berpengaruh pada proses pembelajaran dan diharapkan mampu meningkatkan kemampuan yang ingin dicapai. Menurut Sumartini (2015: 2), salah satu pembelajaran yang dapat 
meningkatkan kemampuan penalaran matematis siswa adalah pembelajaran berbasis masalah. Hal ini sesuai dengan pendapat Kodariyati (2016: 96), bahwa Problem Based Learning (PBL) merupakan salah satu model pembelajaran berbasis masalah yang dapat membantu pemahaman siswa terhadap materi pelajaran, yang memungkinkan dikembangkannya keterampilan berpikir siswa. . Jadi dikatakan berhasil suatu proses pembelajaran di kelas jika terjadi perubahan perilaku positif siswa dalam kehidupannya (Jatisunda, 2017)

Berdasarkan uraian yang dijelaskan, tujuan dari penelitian ini adalah untuk mendeskripsikan perbedaan peningkatan kemampuan penalaran matematis siswa yang menggunakan Problem Based Learning ditinjau dari kemampuan awal matematis (tinggi, sedang, dan rendah).

\section{KAJIAN LITERATUR DAN \\ a. Kemampuan Penalaran Matematis}

Dalam proses pembelajaran biasanya siswa belajar berpikir kritis, kreatif dan mampu bernalar mengenai materi yang diajarkan. Jika siswa mampu bernalar dengan baik, maka salah satu tujuan pembelajaran matematika telah tercapai. Sesuai dengan pernyataan Ainun (2015: 56), bahwa kemampuan penalaran matematis merupakan bagian yang utama yang hendak dicapai dalam tujuan pembelajaran matematika.

Hal ini menunjukkan bahwa kemampuan penalaran sangatpenting untuk dimiliki siswa. Sesuai dengan pendapat Isnaeni dkk (2018: 108), mengemukakan bahwa dalam mengembangkan penguasaan konsep pelajaran yang baik, penalaran siswa sangat dibutuhkan untuk memberi arti dalam proses belajar mandiri, misalnya dengan adanya keinginan untuk mencari hubungan konseptual antara pengetahuan yang dimiliki dengan yang dipelajari di dalam pembelajaran. Hal tersebut diperjelas oleh Bernard (2014: 426) bahwa kemampuan penalaran meliputi: (1) penalaran umum yang berhubungan dengan kemampuan untuk menemukan penyelesaian atau pemecahan masalah; (2) kemampuan yang berhubungan dengan penarikan kesimpulan, seperti pada silogisme, dan yang berhubungan dengan kemampuan menilai implikasi dari suatu argumentasi; dan (3) kemampuan untuk melihat hubunganhubungan, tidak hanya hubungan antara benda-benda tetapi juga hubungan antara ide-ide, dan kemudian mempergunakan hubungan itu untuk memperoleh benda-benda atau ide-ide lain.

Berikut ini indikator kemampuan penalaran matematis menurut Sumarmo (dalam Hendriana, 2017: 2930), diklasifikasikan ke dalam dua kelas besar yaitu (1) Penalaran induktif matematis; dan 2) Penalaran deduktif matematis. Kemudian Sumarmo merinci indikator penalaran induktif matematis yaitu (1) Penalaran transduktif, menarik kesimpulan dari satu kasus pada satu kasus lainnya; (2) Penalaran analogi, menarik kesimpulan berdasarkan keserupaan proses atau data; (3) Penalaran generalisasi, menarik kesimpulan umum berdasarkan sejumlah data terbatas yang dicermati; (4) Memperkirakan jawaban, solusi atau kecenderungan, interpolasi dan ekstrapolasi; (5) Memberi penjelasan terhadap model, fakta, sifat, hubungan atau pola yang ada; (6) Menggunakan pola hubungan untuk menganalisis situasi dan menyusun konjektur.

Selanjutnya, indikator penalaran deduktif matematis yaitu (1) Melaksanakan perhitungan 
berdasarkan aturan atau rumus tertentu; (2) Menarik kesimpulan logis (penalaran logis) yang dirinci ke dalam sub indikator yaitu penalaran proporsional, penalaran proporsional atau berdasarkan aturaan inferensi, memeriksa validitas argumen, membuktikan dan menyusun argumen yang valid, serta penalaran probabilitas, penalaran kombinatorial; (3) Menyusun pembuktian langsung, pembuktian tak langsung dan pembuktian dengan induksi matematika.

\section{b. Problem Based Learning}

Menurut Yusri (2018: 53), pembelajaran dengan model Problem Based Learning adalah pendekatan pengajaran yang memberikan tantangan bagi siswa untuk mencari solusi dari permasalahan dunia nyata secara individu maupun kelompok. Menurut Albanese dkk (dalam Khoiri, 2013: 116), mengungkapkan bahwa PBL selain melengkapi siswa dengan pengetahuan, PBL juga bisa digunakan untuk meningkatkan keterampilan pemecahan masalah, kemampuan berpikir kritis dan kreatif, belajar sepanjang hayat, keterampilan komunikasi, kerjasama kelompok, adaptasi terhadap perubahan dan kemampuan evaluasi diri.

Menurut Kemdikbud 2014 berikut ini sintaks model Problem Based Learning yaitu:

1) Fase 1 orientasi siswa terhadap masalah.

a) Guru menjelaskan tujuan pembelajaran, menjelaskan logistik yang dibutuhkan

b) Guru memotivasi peserta didik untuk terlibat aktif dalam pemecahan masalah yang dipilih.

2) Fase 2 mengorganisasikan siswa untuk belajar.
Guru membantu peserta didik mendefinisikan dan mengorganisasikan tugas belajar yang berhubungan dengan masalah tersebut.

3) Fase 3 membimbing penyelidikan individu maupun kelompok.

Guru mendorong peserta didik untuk mengumpulkan informasi yang sesuai, melaksanakan eksperimen untuk mendapatkan penjelasan dan pemecahan masalah.

4) Fase 4 mengembangkan dan menyajikan hasil karya dan memamerkannya.

Guru membantu peserta didik dalam merencanakan dan menyiapkan karya yang sesuai seperti laporan, model dan berbagi tugas dengan teman.

5) Fase 5 menganalisis dan mengevaluasi proses pemecahan masalah.

Guru membantu peserta didik untuk melakukan refleksi atau evaluasi terhadap penyelidikan mereka dan proses-proses yang mereka gunakan.

\section{METODE PENELITIAN}

Metode penelitian ini adalah kuantitatif deskriptif dengan desain penelitian Pre-Eksperimental bentuk The One Group Pretest-Posttest Design. Desain ini terdapat pretest sebelum diberi perlakuan dan terdapat posttest setelah diberikan perlakuan.

Populasi dalam penelitian ini adalah seluruh siswa kelas XI SMA Negeri 1 Kasokandel, Kecamatan Kasokandel Kabupaten Majalengka tahun ajaran 2018/2019. Sampel penelitian pada penelitian ini yaitu di kelas XI MIPA 3 sebagai kelas eksperimen dengan jumlah siswa 32 orang yang terdiri dari 4 orang siswa dan 28 orang siswi. Teknik 
pengambilan sampel pada penelitian ini dilakukan melalui purposive sampling. Kemudian sampel tersebut dibagi menjadi 3 kelompok berdasarkan tingkat Kemampuan Awal Matematis (KAM) yaitu kelompok KAM tinggi, sedang, dan rendah. Instrumen yang digunakan dalam penelitian ini adalah instrumen tes dan non tes. Instrumen tes yaitu berupa soal-soal kemampuan penalaran matematis siswa berbentuk esay yang digunakan untuk pretest dan posttest sebanyak 3 soal dengan 2 sub pertanyaan dari masing-masing soal, sedangkan instrumen non tes yaitu berupa angket respon siswa terhadap pembelajaran matematika dengan pendekatan yang diberikan dan lembar observasi yang memuat aktivitas siswa serta guru selama pembelajaran dan bahan ajar yang digunakan.

Analisis data pada penelitian ini berisi paparan mengenai teknik analisis data yang diperoleh selama penelitian. Data kuantitatif/data hasil tes dianalisis dengan menggunakan uji statistik berupa software IBM SPSS 21. Sebelum menentukan uji statistik, data kuantitatif diuji normalitas dan homogenitas terlebih dahulu. Berikut ini tahapan dalam mengolah data: (1) Memberikan skor jawaban siswa sesuai dengan kunci jawaban dan rubrik penilaian. Selanjutnya menghitung statistik deskriptif skor pretest dan posttest; (2) Melakukan uji normalitas; (3) Melakukan uji homogenitas; (4) Melakukan uji t (Paired Sample T-Test); (5) Melakukan uji One Way ANOVA; dan (6) Melakukan uji lanjutan Post Hoc dengan tipe Scheffe.

Selanjutnya untuk data kualitatif/data hasil non tes dianalisis dengan statistik deskriptif untuk mengetahui gambaran umum tentang respon siswa terhadap pembelajaran matematika dengan menggunakan Problem Based Learning. Penyajian hasil analisis dilakukan dengan membuat tabel persentase.

\section{HASIL DAN PEMBAHASAN}

Berdasarkan hasil pengolahan data dari hasil penelitian tentang peningkatan kemampuan penalaran matematis siswa, berikut ini hasil perhitungan statistik deskriptif pretest dan posttest:

Tabel 1

Hasil Analisis Data Statistik

Deskriptif Pretest-Posttest

\begin{tabular}{|c|c|c|c|c|}
\hline Data & Mean & SD & Min & Mak \\
\hline Tinggi & 0,67 & 0,052 & 58 & 74 \\
\hline Sedang & 0,56 & 0,054 & 45 & 64 \\
\hline Rendah & 0,44 & 0,057 & 37 & 51 \\
\hline
\end{tabular}

Berdasarkan Tabel 1 diperoleh bahwa rata-rata dari kelompok tinggi 0,67 sedang 0,56 rendah 0,44 , standar deviasi dari kelompok tinggi 0,052 sedang 0,054 rendah 0,057, minimum dari kelompok tinggi 58 sedang 45 rendah 37, maksimum dari kelompok tinggi 74 sedang 64 rendah 51 .

Terlihat adanya perbedaan rata-rata yang selisihnya tidak terlalu jauh antara kelompok tinggi, sedang dan rendah. Dengan demikian dapat dikatakan bahwa terjadi peningkatan pembelajaran melalui Problem Based Learning untuk kemampuan penalaran matematis siswa.

Selanjutnya hasil uji normalitas pretest dan posttest dengan uji ShapiroWilk menggunakan IBM SPSS 21. Berikut hasil pengujian statistiknya:

Tabel 2

Hasil Uji Normalitas Pretest-Posttest

\begin{tabular}{|c|c|c|c|}
\hline \multirow{2}{*}{ Data } & \multicolumn{3}{|c|}{ Shapiro-Wilk } \\
\cline { 2 - 4 } & Statistic & Df & Sig. \\
\hline Tinggi & 0,914 & 6 & 0,464 \\
\hline Sedang & 0,948 & 22 & 0,283 \\
\hline Rendah & 0,970 & 4 & 0,843 \\
\hline
\end{tabular}


Berdasarkan Tabel 2 di atas dengan menggunakan uji Saphiro-Wilk pada kelompok tinggi, sedang, dan rendah diperoleh hasil uji normalitas dengan signifikansi kelompok tinggi 0,464 kelompok sedang 0,283 dan kelompok rendah 0,843. Berdasarkan kriteria pengujian $\mathrm{H}_{0}$ diterima, karena nilai signifikansinya lebih besar dari taraf signifikansinya $(\alpha=0,05)$. Sehingga hasil pengujian Shapiro-Wilk dapat disimpulkan bahwa data nilai pretest dan posttest berdistribusi normal.

Karena data berdistribusi normal, selanjutnya dilakukan uji homogenitas. Berikut ini hasil uji homogenitas pretest dan posttest :

Tabel 3

Hasil Uji Homogenitas PretestPosttest

\begin{tabular}{|c|c|c|c|}
\hline Levene Statistic & df1 & df2 & Sig. \\
\hline 0,345 & 2 & 29 & 0,711 \\
\hline
\end{tabular}

Pada Tabel 3 di atas, diperoleh hasil uji homogenitas dengan nilai signifikansinya 0,711 . Hal ini menunjukan bahwa data bersifat homogen, karena nilai Sig. > 0,05 maka $\mathrm{H}_{0}$ diterima. Dengan demikian dapat disimpulkan bahwa variansi data dari sampel yang dianalisis adalah homogen.

Setelah didapat bahwa data berdistribusi normal dan homogen, selanjutnya melakukan uji $\mathrm{t}$ (Paired Sample T-Test). Berikut hasil uji t pretest dan posttest:

\section{Tabel 4}

\section{Hasil Uji t (Paired Sample T-Test)}

\section{Pretest-Posttest}

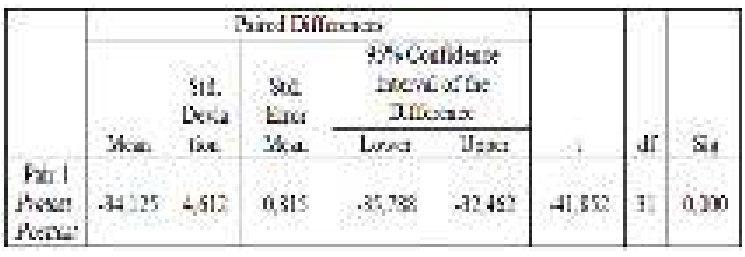

Berdasarkan hasil uji $t$ (Paired Sample T-Test) pada tabel 4 di atas, diperoleh nilai signifikansinya yaitu
0,00 . Data tersebut menunjukkan bahwa nilai Sig. < 0,05, maka H0 di tolak. Artinya perbedaan kemampuan penalaran matematis siswa sesudah pembelajaran lebih baik daripada sebelum pembelajaran dengan menggunakan Problem Based Learning.

Kemudian untuk mengetahui perbedaan peningkatan kemampuan matematis siswa ditinjau dari KAM (tinggi, sedang dan rendah), dilanjutkan dengan uji One-Way ANOVA. Berikut hasil anaisisnya:

Tabel 5

Hasil Uji One-Way ANOVA Pretest-Posttest

\begin{tabular}{|c|c|c|c|c|c|}
\hline & $\begin{array}{l}\text { Sirs at } \\
5 \text { simm. }\end{array}$ & DI & Nensiane: & $\mathrm{F}$ & $\mathbb{E}_{65}$ \\
\hline 3tvas Guns, & 0121 & 2 & $0,2 \leq 0$ & $201+1$ & $0 \div 8$ \\
\hline Walis Gruyo & $0 \cos$ & 23 & 0,23 & & \\
\hline$T(x) \mid$ & $07 m$ & 31 & & & \\
\hline
\end{tabular}

Berdasarkan hasil uji hipotesis (uji one-way ANOVA) pada Tabel 5 diatas, diperoleh nilai signifikansinya yaitu 0,00 . Data tersebut menunjukkan bahwa nilai Sig. < 0,05, maka H0 di tolak. Dengan demikian, terdapat perbedaan peningkatan kemampuan penalaran matematis siswa yang menggunakan Problem Based Learning ditinjau dari kemampuan awal matematis (tinggi, sedang, dan rendah).

Berikut ini hasil uji lanjutan Post Hoc dengan tipe Scheffe setelah dilakukan uji one-way ANOVA :

\section{Tabel 6}

Hasil Uji Post Hoc (Scheffe)

Pretest-Posttest

\begin{tabular}{|c|c|c|}
\hline \multirow{2}{*}{ Kategori } & Kategori & Sig. \\
\hline \multirow{2}{*}{ Tinggi } & Sedang & 0,001 \\
\cline { 2 - 3 } & Rendah & 0,000 \\
\hline \multirow{2}{*}{ Sedang } & Tinggi & 0,001 \\
\cline { 2 - 3 } & Rendah & 0,002 \\
\hline \multirow{2}{*}{ Rendah } & Tinggi & 0,000 \\
\cline { 2 - 3 } & Sedang & 0,002 \\
\hline
\end{tabular}

Berdasarkan hasil uji pada tabel 6 di atas, diperoleh bahwa terdapat perbedaan peningkatan kemampuan 
penalaran matematis siswa yang menggunakan Problem Based Learning ditinjau dari kemampuan awal matematis (tinggi, sedang, dan rendah). Hal ini terlihat perbandingan kelompok tinggi-rendah dengan nilai signifikansi 0,000, kelompok tinggi-sedang dengan nilai signifikansi 0,001, dan kelompok sedang-rendah dengan nilai signifikansi sebesar 0,002.

Selanjutnya adalah hasil analisis dari lembar observasi aktivitas siswa dan guru. Berikut tabel persentase aktivitas siswa:

Tabel 7

Persentase Aktivitas Siswa

\begin{tabular}{|l|c|c|c|}
\hline $\begin{array}{c}\text { Pertemua } \\
\text { n ke- }\end{array}$ & $\begin{array}{c}\text { Juml } \\
\text { ah } \\
\text { Skor }\end{array}$ & $\begin{array}{c}\text { Perse } \\
\text { ntase } \\
(\%)\end{array}$ & Kategori \\
\hline $\begin{array}{l}\text { Pertemua } \\
\text { n ke-1 }\end{array}$ & 78 & $57 \%$ & Baik \\
\hline $\begin{array}{l}\text { Pertemua } \\
\text { n ke-2 }\end{array}$ & 97 & $71 \%$ & Baik \\
\hline $\begin{array}{l}\text { Pertemua } \\
\text { n ke-3 }\end{array}$ & 103 & $76 \%$ & $\begin{array}{c}\text { Sangat } \\
\text { Baik }\end{array}$ \\
\hline $\begin{array}{l}\text { Pertemua } \\
\text { n ke-4 }\end{array}$ & 122 & $90 \%$ & $\begin{array}{c}\text { Sangat } \\
\text { Baik }\end{array}$ \\
\hline \multicolumn{2}{|c|}{ Rata-rata } & $73,5 \%$ & Baik \\
\hline
\end{tabular}

Berdasarkan Tabel 7 dari keempat pertemuan pembelajaran di atas dapat disimpulkan bahwa rata-rata keterlaksanaan aktivitas siswa dengan menggunakan Problem Based Learning adalah 73,5\% dengan kategori baik. Hal ini menunjukkan bahwa aktivitas keterlaksanaan aktivitas siswa setiap tahapan pembelajaran secara keseluruhan dapat terlaksana.

Selain persentase aktivitas siswa, berikut ini adalah tabel persentase aktivitas guru:

\begin{tabular}{|l|c|c|c|}
\hline $\begin{array}{c}\text { Pertemu } \\
\text { an ke- }\end{array}$ & $\begin{array}{c}\text { Jumlah } \\
\text { Skor }\end{array}$ & $\begin{array}{c}\text { Persen } \\
\text { tase } \\
(\%)\end{array}$ & $\begin{array}{c}\text { Katego } \\
\text { ri }\end{array}$ \\
\hline $\begin{array}{l}\text { Pertemu } \\
\text { an ke-1 }\end{array}$ & 95 & $70 \%$ & Baik \\
\hline $\begin{array}{l}\text { Pertemu } \\
\text { an ke-2 }\end{array}$ & 102 & $75 \%$ & $\begin{array}{c}\text { Sangat } \\
\text { Baik }\end{array}$ \\
\hline $\begin{array}{l}\text { Pertemu } \\
\text { an ke-3 }\end{array}$ & 108 & $80 \%$ & $\begin{array}{c}\text { Sangat } \\
\text { Baik }\end{array}$ \\
\hline $\begin{array}{l}\text { Pertemu } \\
\text { an ke-4 }\end{array}$ & 132 & $97 \%$ & $\begin{array}{c}\text { Sangat } \\
\text { Baik }\end{array}$ \\
\hline \multicolumn{2}{|c|}{ Rata-rata } & $80,5 \%$ & $\begin{array}{c}\text { Sangat } \\
\text { Baik }\end{array}$ \\
\hline
\end{tabular}

Berdasarkan Tabel 8 dari keempat pertemuan pembelajaran di atas dapat disimpulkan bahwa rata-rata keterlaksanaan aktivitas guru dengan menggunakan Problem Based Learning adalah $80,5 \%$ dengan kategori sangat baik. Hal ini menunjukkan bahwa aktivitas keterlaksanaan guru setiap tahapan pembelajaran secara keseluruhan dapat terlaksana.

Selanjutnya, hasil analisis lain yaitu angket respon siswa terhadap pembelajaran matematika dengan menggunakan Problemm Based Learning sebagai berikut:

\begin{tabular}{|c|c|c|c|c|c|}
\hline 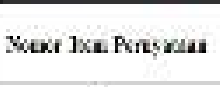 & 5IS & T5 & 5 & S5 & 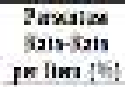 \\
\hline : & $\pi i$ & $23,2 \%$ & $53,35:$ & $\because y$ yt: & $11 \%$ \\
\hline 2 & Fi & $11+\pi$ & 53,$35 ;$ & $\theta:$ & 54.3 \\
\hline 3 & $x$ & 34335 & $625 \%$ & $3,13: 6$ & $5 x 33$ \\
\hline 4 & 3,119 & $37,3 \times 5$ & 52,$33 ;$ & $\cos 5$ & 12,41 \\
\hline 5 & $\mathrm{Th}$ & $6568 \%$ & $3+3 \%$ & is: & $5+53$ \\
\hline$s$ & $v_{1}^{2}=4$ & 73.34 & $25 S 3 \%$ & 0 & $E 317$ \\
\hline 1 & Fi & $25+58$ & $25^{0} \cdot 3=$ & 135 & $5 \times 2 \%$ \\
\hline 8 & $\bar{N}$ & TSF & 62sin & in & $43: 3$ \\
\hline 3 & $\pi i$ & 53,35 & 31,35: & $t 25:$ & 12,45 \\
\hline 18 & $\pi$ & $3435 ;$ & $8,2,5)$ & fr: & 545 \\
\hline L. & $x$ & $\$ 3,2 \pi ;$ & $13,97 \%$ & os & $\$ 2,73$ \\
\hline 12 & $12 \leq \gamma_{i}$ & $35,0 n_{i}$ & $2298:$ & $\theta:$ & $\leq, 33$ \\
\hline 13 & 9,196 & $\$ 3 \%$ & $4 \leqslant 37 \%$ & cos: & 474 \\
\hline It & 213 & \$23표 & $333 \mathrm{~K}$ & $o n$ & 4211 \\
\hline 15 & $\pi$ & 4375 & 55268 & tict: & 517 \\
\hline 16 & M. & $125 \mathrm{r}$ & $5527 \%$ & $31 \mathrm{~K}:$ & $4(5)$ \\
\hline 11 & $r_{i}$ & y.25; & EYS: & 658 & 13.2: \\
\hline 15 & 9.125 & $2428 \%$ & $410^{*}$ & ins & 452 \\
\hline 13 & $x_{i}$ & estsi: & $25,2 x:$ & 3385 & $52,2)$ \\
\hline II & $\pi i$ & $3133 ;$ & 15,$12 ;$ & $\theta:$ & sits \\
\hline \multicolumn{4}{|c|}{ 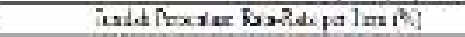 } & & 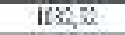 \\
\hline \multicolumn{5}{|c|}{ 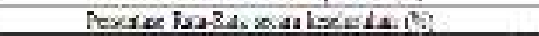 } & $3 L \mathbb{3}$ \\
\hline
\end{tabular}

Berdasarkan hasil perhitungan Tabel 8 Persentase Aktivitas Guru tersebut diperoleh persentase rata-rata 
jawaban siswa secara kesseluruhan sebesar 51,63\%. Hal ini menunjukkan bahwa persentase rata-rata respon siswa terhadap pembelajaran matematika dengan menggunakan Problem Based Learning sebesar 51,63\%. Artinya sebagian besar siswa memiliki respon yang baik terhadap pembelajaran matematika dengan menggunakan Problem Based Learning.

Hasil analisis respon siswa di atas, terlihat bahwa siswa bersikap positif dan sebagian besar siswa memiliki respon yang baik terhadap pembelajaran dengan menggunakan Problem Based Learning. Penggunaan Problem Based Learning juga dapat meminimalisir siswa yang kurang aktif, selain itu akan membuat siswa menjadi lebih aktif karena ada interaksi langsung dengan siswa lain pada saat berdiskusi kelompok untuk memecahkan suatu permasalahan dan siswa dapat belajar dengan baik.

Hal tersebut didukung dengan pendapat Ali dkk (2010: 68) bahwa Problem Based Learning merupakan sebuah model pembelajaran yang berpusat pada siswa dari pendengar informasi pasif menjadi aktif, mengembangkan masalah dan keterampilan pemecahan masalah.

\section{KESIMPULAN}

Berdasarkan hasil analisis, pembahasan, dan temuan penelitian, maka dapat disimpulkan sebagai berikut: (1) Perbedaan kemampuan penalaran matematis siswa sesudah pembelajaran lebih baik daripada sebelum pembelajaran dengan menggunakan Problem Based Learning. Hal ini dapat dilihat dengan nilai Sig $=0,00<0,05$; (2) Terdapat perbedaan peningkatan kemampuan penalaran matematis siswa yang menggunakan Problem Based Learning ditinjau dari kemampuan awal matematis (tinggi, sedang, dan rendah).
Hal ini terlihat perbandingan kelompok tinggi-rendah dengan nilai signifikansi 0,000, kelompok tinggi-sedang dengan nilai signifikansi 0,001, dan kelompok sedang-rendah dengan nilai signifikansi sebesar 0,002; (3) Hasil analisis angket respon siswa juga menunjukkan bahwa sebagian besar siswa memiliki respon positif terhadap penggunaan Problem Based Learning dengan nilai rata-rata keseluruhan sebesar $51,63 \%$.

\section{REFERENSI}

Ainun, Nur. (2015). Peningkatan Kemampuan Penaalaran Matematis Siswa Madrasah Aliyah Melalui Model Pembelajaran Kooperatif Tipe Teams Games Tournament. Jurnal Peluang. 4, (1), 55-63.

Ali, R. et. al. (2010). Effect of Using Problem Solving Method in Teaching Mathematics on the Achievement of Mathematics Students. Asian Social Science. 6, (2), 67-72.

Bernard, Martin. (2014). Meningkatkan Kemampuan Penalaran Matematik Siswa SMA Melalui Game Adobe Flash CS 4. Prosiding Seminar Nasional Pendidikan Matematika STKIP Siliwangi. 2, 205-213.

Hendriana, H, Rohaeti, E. E, dan Sumarmo, U. (2017). Hard Skill dan Soft Skills. Unnes Journal of Mathematics Education. Bandung: Refika Aditama.

Isnaeni, S, dkk. (2018). Analisis Kemampuan Penalaran Matematis dan Kemandirian Belajar Siswa SMP Pada Materi Persamaan Garis Lurus. Journal of Medives. 2, (1), 107115.

Khoiri, W., Rochmad, dan Cahyono, A. N. (2013). "Problem Based Learning 
Berbantuan Multimedia Dalam Pembelajaran Matematika Untuk Meningkatkan Kemampuan Berpikir Kreatif". Unnes Journal of Mathematics Education. 2, (1), 115-121.

Jatisunda, M. G. (2017). Hubungan selfefficacy siswa SMP dengan kemampuan pemecahan masalah matematis. Jurnal THEOREMS (The Original Research of Mathematics), 1(2).

Kodariyati, L., dan Astuti, B. (2016). Pengaruh Model PBL Terhadap Kemampuan Komunikasi dan Pemecahan Masalah Matematika Siswa Kelas V Sd. Jurnal Prima Edukasia. 4, (1), 93-106.

NCTM. (2000). Principles and Standards for School Mathematics. USA : NCTM

Nuridawani, dkk. (2015). Peningkatan Kemampuan Penalaran Matematis dan Kemandirian Belajar Siswa Madrasah Tsanawiyah (MTs) Melalui Pendekatan Contextual Teaching And Learning (CTL). Jurnal Didaktik Matematika. 2, (2), 59-71.

Sumartini, Tina Sri. (2015). Peningkatan Kemampuan Penalaran Matematis Siswa Melalui Pembelajaran Berbasis Masalah. Moshafara. 5, (1), 1-10.

Yusri, A. Y. (2018). "Pengaruh Model Pembelajaran Problem Based Learning Terhadap Kemampuan Pemecahan Masalah Matematika Siswa Kelas VII di SMP Negeri Pangkajene". Jurnal Mosharafa. 7, (1), 51-62. 